\title{
SLOPE ANGLE ESTIMATION OF AMOANDA EAST PIT OF ABOSSO GOLD FIELDS, GHANA
}

\author{
G. Agyei ${ }^{1, *}$, L. Ocran ${ }^{2}$ and E. M. Buaba ${ }^{3}$ \\ 1, 2,3, DePARTMENT OF Mining Engineering, Univ. Of Mines \& TeChnology, P.O. Box 237, TARKWA, GHANA \\ E-mail addresses: 1 gagyei@umat.edu.gh, 2 lucyocran601@gmail.com, ${ }^{3}$ embuaba@umat.edu.gh
}

\begin{abstract}
This paper determines the possible modes of slope failure, and the effect of increasing the slope angle of the Amoanda East Pit Wall of Abosso Gold Fields Limited, Damang Mine by $5^{\circ}$ and $10^{\circ}$ from $70^{\circ}$ because the designed slope angle $\left(70^{\circ}\right)$ will increase ore losses at Amoanda East. The methods employed include field geotechnical mapping of the slope face, and kinematic analysis using DIPS 6.0 software to analyse the modes of failures. Based on the kinematic analysis conducted using the slope angle per design ( $\left.70^{\circ}\right)$, it was found that the percentage of toppling, planar and wedge failures obtained were $20.05 \%, 5.41 \%$ and $0 \%$ respectively. Also, when the slope angle of Amoanda East Pit Wall was increased by $5^{\circ}\left(75^{\circ}\right)$ and $10^{\circ}\left(80^{\circ}\right)$, there was percentage increase in toppling and planar failures of (0.12 and 0.99$) \%$ and (2.59 and 4.18) \% respectively, with no increment in wedge failure. Hence there is the possibility of planar and toppling failure with no wedge failure occurring at the Amoanda East. It is therefore recommended that, since the percentage increment in toppling and wedge were not significant when the slope angle was increased, the mine should continue to increase the slope angle by $5^{\circ}$ and $10^{\circ}$ from $70^{\circ}$.
\end{abstract}

Keywords: Slope, Toppling, Planar, Failures, Open Pit, Kinematic

\section{INTRODUCTION}

The commencement of mining operations in the Amoanda Pit Cutback of the Abosso Goldfields Limited (AGL) began in March, 2016. Current slope parameters for the Amoanda Pit extension on the northern side and going into the bigger pit has been based on previous work carried out by SRK (Steffen, Robertson and Kirsten) Consulting Engineers (Australia) and also information collected during previous mining (mapping exercise) of the pit to augment initial data.

During mining, widely spaced joints to massive dolerite intrusive structures favourable to stability were encountered at the mid-east portions trending south. This was not accounted for in the initial study report because there was no information about it at that time even though they inferred it. The batter angle was then steepened to $70^{\circ}$ from the original $60^{\circ}$ in the design (as built confirmed). The pit was mined to the bottom with no slope failures or instability.
Therefore the practices carried out during previous Amoanda mining and encountered conditions of the rock mass informed the decision for the optimisation of the slope configuration [1]. Slope either occurs naturally, or humans engineer them. An understanding of geology, hydrology, and soil properties are essential in applying slope stability concepts correctly. Analyses are based upon a model that appropriately represents site subsurface conditions, ground behaviour, and applied loads. Judgments concerning an acceptable risk or safety factors are made to evaluate the outcomes of analyses. These analyses are performed at the beginning and throughout the life of mine during planning and design [2]. When handling slopes in general and slope stability analysis specifically, previous geological and geotechnical experience in an area are valuable. The objectives of slope stability analyses are to [3]:

\footnotetext{
* Corresponding author, tel: +233- 245-821 - 539
} 
i. Evaluate the stability of slopes under short-term and long-term conditions.

ii. Assess the possibility of slope failure regarding natural or present engineered slopes.

iii. Examine slope stability and to understand failure mechanisms and the impact of environmental factors.

iv. Enable the redesign of failed slopes and the planning and design of preventive and remedial measures, where vital.

Slope failure takes place when the downward movements of material due to gravity and shear stresses exceed the shear strength. Consequently, factors that tend to increase the shear stresses or decrease the shear strength increase the chances of failure of a slope. These factors, according to Varnes

[5] consist of:

i. Geological structure;

ii. Groundwater conditions;

iii. Excavation methods in rocks; and

iv. Slope geometry.

Failure of the intact rock is seldom a problem in these instances where deformation and failure are caused by sliding along individual discontinuity surfaces or lines of intersection of surfaces [6]. Alternatively, discontinuities may only indirectly affect stability where their length is much shorter than the slope dimensions, such as an open pit mine slope where no single discontinuity controls stability [6].

Groundwater pressures constitute a significant factor in all slope stability problems, and an understanding of the role of subsurface groundwater is an essential requirement for any meaningful slope design $[7,8]$. The strength of jointed rock masses is very dependent upon the interlocking between individual rock pieces.

This interlocking is easily destroyed, and careless blasting during excavation is one of the most common causes of slope instability. Often, more importantly, existing internal planes of incipient weakness, which before blasting were not visible, have opened or widened due to the pressure of the blasting gasses and the shock wave, and therefore become visible [9]. In the case of huge open pit mine blasts; this damage can extend as much as $100 \mathrm{~m}$ behind the final row of blast holes. This is because the blast is designed to achieve a specific purpose, which is generally to produce a fractured rock mass that can be excavated using a given piece of equipment [6]. In open Pit mining, with each successive pushback of a slope, the depth of the pit will increase, and there may need to be a corresponding decrease in the overall slope angle. For the bench face angle, this may be governed by the orientation of a predominant joint set if there are joints that dip out of the face at a steep angle. If this situation does not exist, then the bench angle will be related to the overall slope geometry, and whether single benches are combined into multiple benches. One factor that may influence the maximum height of individual benches is the vertical reach of excavating equipment, to limit the risk accidents due to the collapse of the face.

The conventional limiting equilibrium method investigates the equilibrium of the soil mass tending to slide down under the influence of gravity. This method assumes that shear strengths of the materials along the potential failure surface are governed by linear (Mohr-Coloumb) or non-linear relationship $s$ between shear strength and the normal stress on the failure surface. The analysis provides a factor of safety, defined as a ratio of available shear resistance (capacity) to that required of equilibrium. If the value of factor of safety is less than one (1.0), the slope is unstable [10]. Therefore, at the limit equilibrium point, the factor of safety is unity. The design criterion for limiting equilibrium analysis is expressed in the form of the factor of safety [11].

The Stress-Deformation Technique method is employed at places where the failure does not occur along any clear face [10]. The rock mass is represented by a series of constant structural elements of analysis done to determine the stress at the point within the slope. Reliable estimates of the strength and deformation characteristics of rock masses required for almost any form of analysis used for the design of surface excavations. For surface excavations, the rock mass properties are particularly sensitive to stress relief and blast damage.

The Stereographic Technique is one of the best examples of an initial approach in establishing the possibility of instability is by the method of kinematic analysis of slopes. "Kinematics refers to the study of movement, without reference to the forces that produce it" [11]. For some geometries of slope and discontinuities, a movement is possible (the system is kinematically feasible). For other geometries, a movement is not possible (the system is kinematically infeasible). They do not provide a numerical measure of the degree of safety of the slope, instead of 
whether or not instability is feasible in the first instance. The stereographic projection allows the three-dimensional orientation data to be represented and analysed in two dimensions. Stereographic presentations remove one dimension from consideration so that lines or points can represent planes, and points can represent lines [6]. It provides a way of graphically displaying the data collected essential for the recognition and interpretation of patterns of preferred orientation. In this project, DIPS software was used for visualising structural data using stereonets and statistical analysis of the discontinuity properties. The discontinuities of different orientations and the orientation of the slope face were plotted on the stereonet and the most critical failure geometry, which is possible, determine. Progressive mining and grade control has revealed that there are areas along the East Wall where there are still large sections of high grade ore which would be left in the wall due to the slope configuration (angle).Management wishes to determine the potential of steepening the Amoanda East Wall angles in the lower parts of the pit to extract more of this high grade ore. It must be noted that the steepening of a design slope angle, even though may reduce both the amount of excavation and haulage of waste rock, and hence their costs, it also increases the risk of failure [13].

Hence, this project seeks to conduct stability studies on the Amoanda East Wall and outline the possibility and effect of steepening the wall by $5^{0}$ to $10^{\circ}$ from $70^{\circ}$. In this study, kinematic analyses would also be performed to test for the three basic potential failure modes: planar, wedge, and toppling under gravitational loading. The objective of this paper is to determine the possible modes of failure that can occur at the east wall of the Amoanda Pit to evaluate the effect of increasing the Amoanda East wall slope angle by $5^{\circ}$ to $10^{\circ}$ from $70^{\circ}$.

\section{METHODS AND MATERIALS}

The methods used were:

i. Geotechnical Mapping of the East wall;

ii. Field visits and data collection;

iii. Using Dips software to analyse the potential failure modes (Planar, Toppling and Wedge) and the possibility of steepening the slope angle;

In order to adequately assess the stability of the pit wall, geological data collection of that area is of prime importance. Field geological data collection of the rock mass was done primarily by Window Mapping on the Amoanda East wall using a Brunton Pocket Transit, and kinematic analysis was done by the use of DIPS 6.0 software of Rock science. A diagram showing a Brunton Compass is shown in Figure 1.

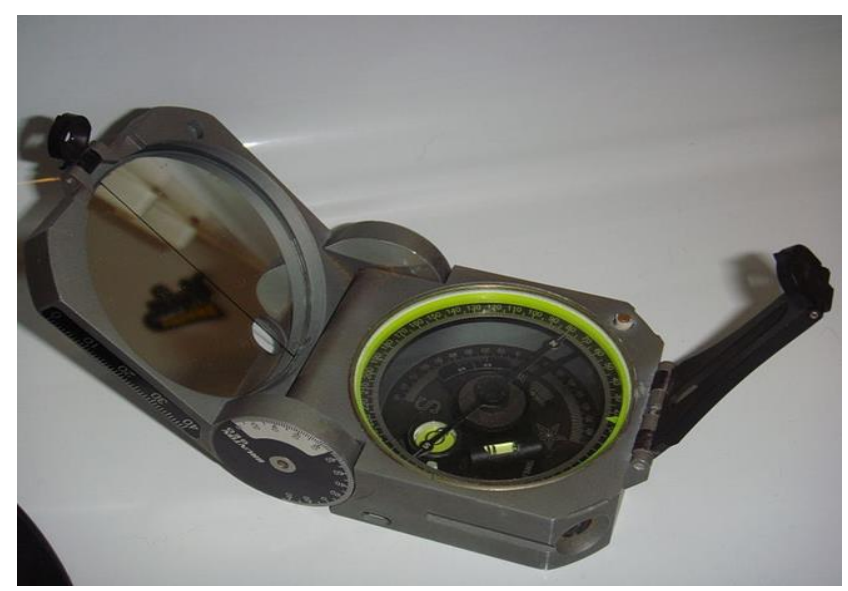

Figure 1: Brunton Compass

The Window Mapping of the Pit Wallis concerned with identifying the discontinuities in the rock mass as well as the rock type. Important parameters which were obtained during the window mapping of the pit include;

i. Face orientation;

ii. Lithology;

iii. Discontinuity Type;

iv. Dip and dip direction;

v. Infill type and width;

vi. Joint spacing;

vii. Roughness;

The selection of the mapping window was based on the complexity of the geological environment, access to the area and the objective of study.

According to [2] the following steps are to be observed when doing field mapping (Window mapping), for kinematic analysis. Hence the following steps were taken:

i. The size of the window used was $30 \mathrm{~m}$ in length.

ii. The ideal locations considered for the windows were the corners since these provided a 3D view of the rock mass.

iii. Development and blast induced fractures were carefully distinguished from the joint sets, in order not to take them as genetic structural joints.

iv. The window ideally covered only a single rock type. This was the ideal opportunity to check the 
accuracy of the geological map for the area, and make amendments where required.

v. A sketch of the wall was made including the window to be mapped, with approximate dimensions. Include rock type, measurement and notes on primary structures in as much details as possible.

vi. Careful records on the site location, co-ordinate and face orientation were recorded on a log sheet which was used for the recordings of window mapping data on the field. These were used to spatially orient the data collected.

The log sheet was used in recording the data on the field. The log is divided into three parts as shown in Table 1.

Table 1: Divisions of the Field Log Sheet

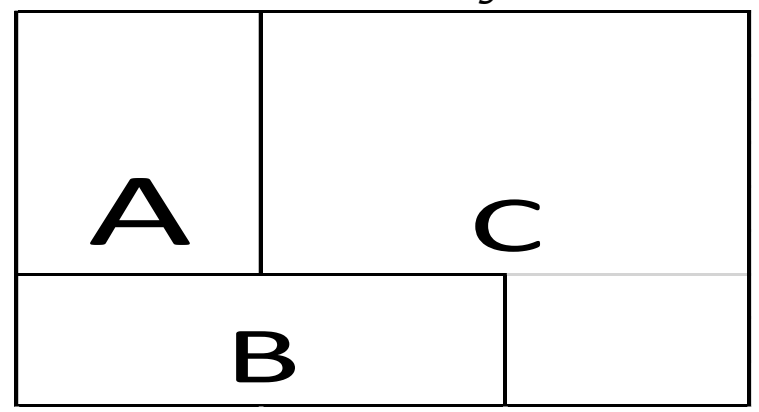

\section{Part $A$}

This part contains general information of the site and surroundings. The data that were taken were:

Rock Type: The rock type of the window.

Weathering: Information on the state of weathering was stated.

Groundwater: The groundwater condition there was stated as either: dry, moist, weeping or wet. Sources of the ground water were recorded and the extent of area affected if any.

Intact Rock strength: The intact rock strength of the rock mass was recorded. This was done with the help of a geological hammer to hit the rock mass to see its strength.

Blasting Effect: Blasting in this case is described as good or bad. Looking at the slope face, the blasting condition can be known as either good or bad.
Comment: This takes care of any relevant information and observations that were observed.

\section{Part B}

This part contains details of each joint set (joints with the same orientation). Corners were used where available for the perspective offered by any particular orientation. Identification of each type of joints were made till all were finished. The following parametres were also considered: average orientation, spacing and roughness.

Average orientation: The average orientation is estimated from the plotting on the stereonet.

Spacing: The minimum, mean and maximum spacing between joints of the same set was measured and recorded with measuring tape.

Roughness: This shows how the texture of the slope looks like. The macro roughness caters for the largescale express of the feature, and was viewed over the entire slope face. Table .2 lists the five different codes that were used to describe each joint set.

Table 2: Macro Joint Conditions

\begin{tabular}{cc}
\hline Code & Description \\
\hline 1 & Straight \\
2 & Slightly undulating \\
3 & Curve \\
4 & Unidirectional \\
5 & Multi- directional way \\
\hline & (Source: [3])
\end{tabular}

The micro joints analysis gives information about the level of surface asperity and the micro relief features of the exposed contacts by looking at the joint set types and using ones hand to rub and feel it to know how smooth or rough the surface is. The Table .3 shows codes that were used in describing the micro joints.

Infill

The types of infill and infill thickness were measured, for example, hematite: $0.05 \mathrm{~mm}$ 
Table 3: Micro Joint Conditions

\begin{tabular}{cc}
\hline Codes & Description \\
\hline 1 & Polished \\
2 & Smooth Planar \\
3 & Rough Planar \\
4 & Slickensides undulating \\
5 & Sooth Undulating \\
6 & Rough Undulating \\
7 & Slickensides stepped \\
8 & Smooth Stepped \\
\hline
\end{tabular}

Part C

Measurement of individual joints were taken. Each joint set number, dip and dip directions were also recorded for approximately 10 joints of the same joint set. Measurements of joints along the entire length of a particular window were recorded. Joint where readings have been taken were marked to avoid duplication and to assist in the definition of sets.

\section{RESULTS AND DISCUSSION \\ 3.1 Kinematic Analysis}

Kinematic analysis is a method used to analyse the potential for the various modes of slope failures that occur due to the presence of unfavorable oriented discontinuities. Analysis of the Amoanda East wall was assessed using DIPS 6.0 to determine the possible modes of failure that can occur and the possibility and effect of increasing the East slope wall angle by $5^{\circ}$ and $10^{\circ}$ from $70^{\circ}$ taking into consideration the procedures proposed by [14] for similar geomechanical conditions at Nkran Pit of Asanco Gold where the slope angle was increased by $5^{\circ}$ and $10^{\circ}$. The authors observed percentage increase in planar, wedge, flexural toppling and direct toppling failure of (1.86 and 7.45$) \%,(1.23$ and 2.81$) \%$, (0.62 and $0.62) \%$ and $(0.60$ and 1.70$) \%$ respectively.

Table 4: The Orientations of the Joint Sets

\begin{tabular}{|c|c|c|c|c|c|c|c|}
\hline \multicolumn{8}{|c|}{ ABOSSO GOLDFIELDS Company LIMITED, DAMANG } \\
\hline \multicolumn{8}{|c|}{ LOCATION: AMOANDA CUTBACK EAST PIT } \\
\hline \multicolumn{2}{|r|}{ joint 1} & \multicolumn{2}{|c|}{ joint 2} & \multicolumn{2}{|c|}{ joint 3} & \multicolumn{2}{|r|}{ joint 4} \\
\hline Dip & dip direction & Dip & dip direction & $\operatorname{dip}$ & dip direction & $\operatorname{dip}$ & dip direction \\
\hline 75 & 098 & 82 & 119 & 80 & 225 & 48 & 320 \\
\hline 79 & 094 & 79 & 171 & 55 & 261 & 39 & 313 \\
\hline 57 & 092 & 57 & 121 & 80 & 251 & 35 & 320 \\
\hline 82 & 095 & 59 & 171 & 82 & 209 & 40 & 315 \\
\hline 79 & 089 & 79 & 109 & 75 & 242 & 46 & 301 \\
\hline 82 & 096 & 75 & 134 & 81 & 239 & 47 & 315 \\
\hline 84 & 076 & 80 & 141 & 84 & 259 & 50 & 302 \\
\hline 70 & 072 & 80 & 151 & 81 & 268 & 89 & 326 \\
\hline 65 & 086 & 72 & 138 & 85 & 261 & 89 & 319 \\
\hline 75 & 085 & 74 & 144 & 80 & 269 & 75 & 321 \\
\hline 84 & 086 & 71 & 140 & 82 & 251 & 79 & 309 \\
\hline 70 & 085 & 75 & 144 & 75 & 206 & 64 & 327 \\
\hline 75 & 081 & 76 & 140 & 72 & 215 & 87 & 321 \\
\hline 84 & 089 & 81 & 174 & 35 & 296 & 89 & 331 \\
\hline 86 & 079 & 84 & 152 & 35 & 269 & 75 & 314 \\
\hline 89 & 068 & 84 & 154 & 46 & 263 & 80 & 327 \\
\hline 86 & 081 & 86 & 176 & 38 & 269 & 81 & 321 \\
\hline 79 & 067 & 87 & 196 & 50 & 281 & 84 & 337 \\
\hline 82 & 074 & 86 & 174 & 50 & 299 & 79 & 324 \\
\hline 85 & 054 & 85 & 177 & 49 & 259 & 78 & 331 \\
\hline 75 & 058 & 80 & 169 & 35 & 269 & 85 & 341 \\
\hline 89 & 055 & 79 & 178 & 39 & 281 & 75 & 326 \\
\hline
\end{tabular}


The mapping data for this analysis is shown in Table 4. It depicts the joint orientations of the discontinuities of the Amoanda East Pit Wall. The field data in Table 4 were transcribed to plot a stereonet to analyse the results, A of Toppling, Planar and Wedge failures. They were analysed on each plot using a mean frictional angle of $35^{\circ}$, dip direction of $270^{\circ}$ per design at the Amoanda East Wall. The data set that was used to perform the qualitative assessment has been made with reference to the density pole concentration lying with each failure.

\subsubsection{Planar Failure Analysis}

Stereonet analysis was performed for planar failure to indicate the unstable zones and the joints set that have the same property and behaviour. The extent of concentration of the joint sets have been displayed beside the stereonet in a legend, frictional cone and a daylight envelope, and planes showing the slope face were plotted during the analysis.

The crescent shape formed by the daylight envelope and the cone of friction encloses the region of planar sliding (unstable zone) and any joint found at that region represent joints which fell at the critical zone.

For this type of failure to occur, the discontinuities must daylight (be seen) on the slope and must be near parallel to the slope face, at an angle greater than the angle of friction of the slope. A kinematic analysis result of planar failure of the Amoanda East wall with a slope angle of $80^{\circ}$ has been illustrated in Fig. 2

\subsubsection{Toppling Failure Analysis}

A toppling failure may result when a steeply dipping discontinuity dips away from the slope face and dips into it at an angle greater than the angle of friction of the slope [5]. In analyzing toppling, a slip limit based on joint frictional cone and pit slope which defines area of restriction or toppling was plotted. The poles that fall within the region created by the slip limit and the toppling envelope, forms the region for toppling failure. The result of toppling failure for slope angle of $80^{\circ}$ has been shown in Fig. 3. The result of the planar analysis has been summarized in Table 5 . A summary of the kinematic analysis for toppling failure, has been shown in Table 6.

\subsubsection{Wedge Failure Analysis}

For wedge failure to occur, the point of intersection between two discontinuities should be enclosed in the plane of friction cone and daylight into the slope face. A kinematic analysis results of wedge failure of the Amoanda East wall with a slope angle of $80^{\circ}$ has been displayed in Fig. 4. A summary of the kinematic analysis for wedge failure, has been shown in Table 7.
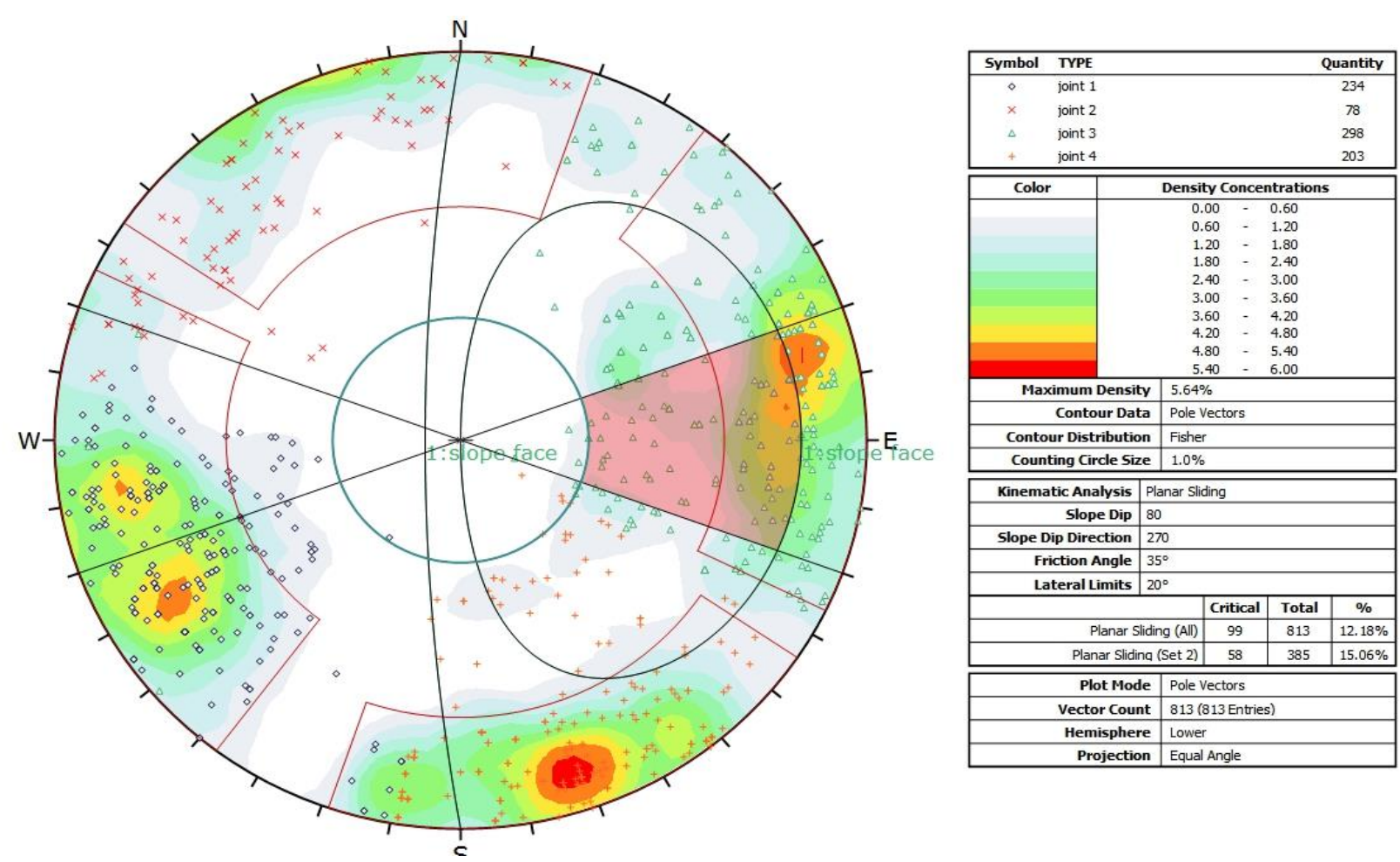

Fig. 2: Planar Analysis of the Amoanda East Wall at $80^{\circ}$ 
Table 5: Kinematic Analysis for Planar Failure

\begin{tabular}{cccccc}
\hline Pit Area & $\begin{array}{c}\text { Slope Dip } \\
\text { Direction }\end{array}$ & $\begin{array}{c}\text { Modes of } \\
\text { Failure }\end{array}$ & $\begin{array}{c}\text { Slope } \\
\text { Angle }\end{array}$ & $\begin{array}{c}\text { Percentage of Total } \\
\text { Planar Failure }\end{array}$ & Comment \\
\hline $\begin{array}{l}\text { Amoanda } \\
\text { East Wall }\end{array}$ & $270^{\circ}$ & $\begin{array}{c}\text { Planar } \\
\text { Failure }\end{array}$ & $70^{\circ}$ & $5.41 \%$ & $\begin{array}{c}\text { Percentage of Planar Failure to } \\
\text { occur at this angle is minimal. }\end{array}$ \\
$\begin{array}{l}\text { Amoanda } \\
\text { East Wall } \\
\text { Amoanda } \\
\text { East Wall }\end{array}$ & $270^{\circ}$ & $\begin{array}{l}\text { Planar } \\
\text { Failure }\end{array}$ & $75^{\circ}$ & $8.00 \%$ & $\begin{array}{c}\text { Percentage of failure is minimal } \\
\text { Percentage of failure is } \\
\text { moderate }\end{array}$ \\
\hline
\end{tabular}
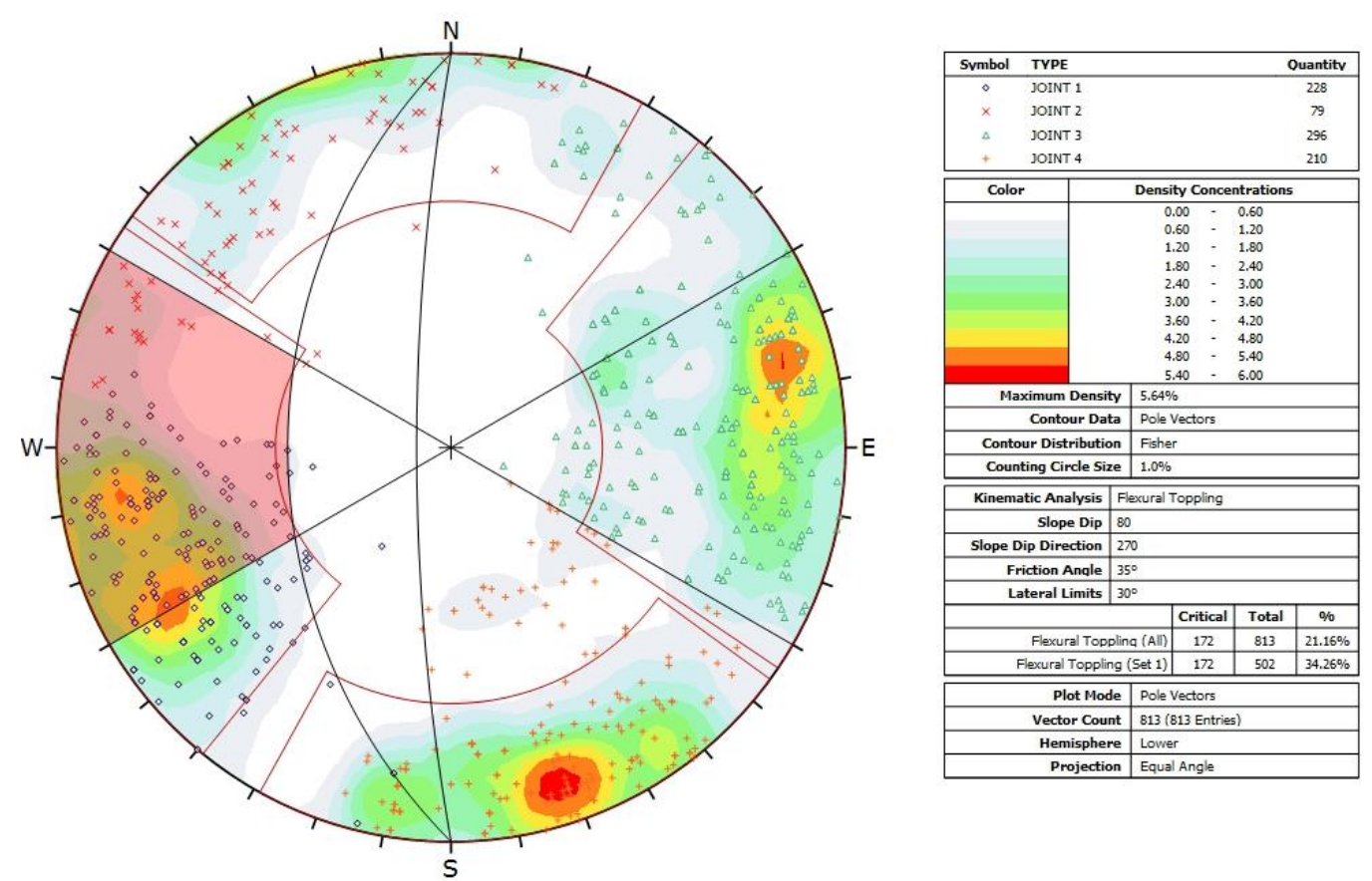

Fig. 3: Toppling Analysis of the Amoanda East Wall at 80

Table 6: Kinematic Analysis for Toppling Failure

\begin{tabular}{|c|c|c|c|c|c|}
\hline Pit Area & $\begin{array}{l}\text { Slope Dip } \\
\text { Direction }\end{array}$ & $\begin{array}{l}\text { Modes of } \\
\text { Failure }\end{array}$ & $\begin{array}{l}\text { Slope } \\
\text { Angle }\end{array}$ & $\begin{array}{l}\text { Percentage of Total } \\
\text { Toppling Failure }\end{array}$ & Comment \\
\hline $\begin{array}{l}\text { Amoanda East } \\
\text { Wall }\end{array}$ & $270^{\circ}$ & $\begin{array}{l}\text { Toppling } \\
\text { Failure }\end{array}$ & $70^{\circ}$ & $20.05 \%$ & $\begin{array}{l}\text { Percentage of Failure } \\
\text { is moderate }\end{array}$ \\
\hline $\begin{array}{c}\text { Amoanda East } \\
\text { Wall }\end{array}$ & $270^{\circ}$ & $\begin{array}{l}\text { Toppling } \\
\text { Failure }\end{array}$ & $75^{\circ}$ & $20.17 \%$ & $\begin{array}{c}\text { Percentage of failure is } \\
\text { moderate }\end{array}$ \\
\hline $\begin{array}{c}\text { Amoanda East } \\
\text { Wall }\end{array}$ & $270^{\circ}$ & $\begin{array}{l}\text { Toppling } \\
\text { Failure }\end{array}$ & $80^{\circ}$ & $21.16 \%$ & $\begin{array}{c}\text { Percentage of failure is } \\
\text { moderate }\end{array}$ \\
\hline
\end{tabular}

Table 7: Kinematic Analysis for Wedge Failure

\begin{tabular}{|c|c|c|c|c|c|}
\hline Pit Area & $\begin{array}{l}\text { Slope Dip } \\
\text { Direction }\end{array}$ & $\begin{array}{l}\text { Modes of } \\
\text { Failure }\end{array}$ & $\begin{array}{l}\text { Slope } \\
\text { Angle }\end{array}$ & $\begin{array}{l}\text { Percentage of Total Wedge } \\
\text { Failure }\end{array}$ & Comment \\
\hline $\begin{array}{c}\text { Amoanda East } \\
\text { Wall }\end{array}$ & $270^{\circ}$ & $\begin{array}{l}\text { Wedge } \\
\text { Failure }\end{array}$ & $70^{\circ}$ & $0.00 \%$ & $\begin{array}{c}\text { No } \\
\text { Failure }\end{array}$ \\
\hline $\begin{array}{c}\text { Amoanda East } \\
\text { Wall }\end{array}$ & $270^{\circ}$ & $\begin{array}{l}\text { Wedge } \\
\text { Failure }\end{array}$ & $75^{\circ}$ & $0.00 \%$ & $\begin{array}{l}\text { No } \\
\text { Failure }\end{array}$ \\
\hline $\begin{array}{c}\text { Amoanda East } \\
\text { Wall }\end{array}$ & $270^{\circ}$ & $\begin{array}{l}\text { Wedge } \\
\text { Failure }\end{array}$ & $80^{\circ}$ & $0.00 \%$ & $\begin{array}{l}\text { No } \\
\text { Failure }\end{array}$ \\
\hline
\end{tabular}



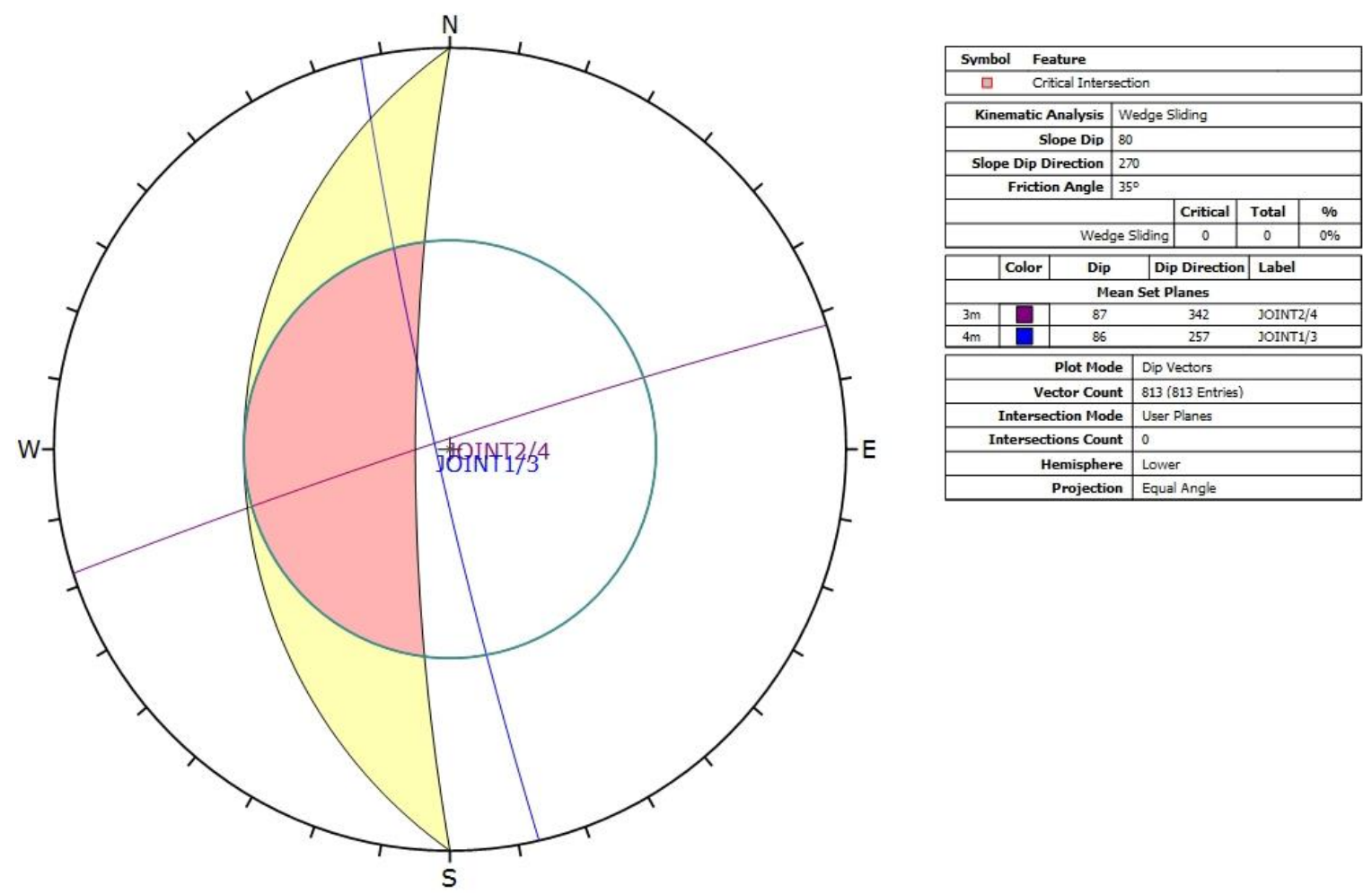

Fig. 4: Wedge Analysis of the Amoanda East Wall at $80^{\circ}$

Since the percentage increments in toppling and planar failure were not significant when the slope angle was increased, management should continue to mine the ore. Before mining, management should determine a suitable factor of safety for planar failure to mine safely.

Controlled blasting should be employed to reduce excessive damage to the walls.

\section{CONCLUSIONS}

Based on the result of the analysis of the work, the following conclusions are made:

i. The combined empirical and analytical methods were applied to evaluate the slope stability. Stability analysis based on the geomechanical properties of the slopes and the kinematic evaluation of the effects of slope dimensioning on the principal modes of failure were also determined. These results may contribute to the current debate about the optimum bench and berm configurations for open pit mines in the Tarkwaian and Upper Birimian Lithology

ii. For the kinematic analysis conducted using the slope angle per design $\left(70^{\circ}\right)$, the percentage of toppling, planar and wedge failures recorded were $20.05 \%, 5.41 \%$ and $0 \%$ respectively.

iii. When the Amoanda East Wall angle was increased by $5^{\circ}$ and $10^{\circ}$, there was percentage increase in toppling and planar of $(0.12$ and 0.99$) \%$, (2.59 and 4.18$) \%$ respectively, with no increment in wedge failure.

Hence there is the possibility of planar and toppling failure occurring, with no wedge failure at the Amoanda East Wall when the angle is increased

\section{REFERENCES}

[1] Hoek, E. and Bray, J. W. Rock Slope Engineering, The Institute of Mining and Metallurgy London, Third Edition, 1981.

[2] Abramson, L. W., Lee, T. S., Sharma S. Boyce, G. M. (2002), "Slope stability and stabilization methods", John Wiley and Sons, New York, USA, 2nd Edition, 712 pp.

[3] Satish, M. P. (2016), "Slope Stability Study", "2nd International Conference in Latest Innovation in Science, Engineering and Management", Goa, India, pp. 295 - 297.

[4] Varnes, D. (1978), "Slope Movement and Processes" in Landslides: Analysis and Control, Special Report, Washington, D.C.: National Academy of Sciences, 176pp.

[5] Hoek, E. and Brown, E. T. (1988), "The HoekBrown failure criterion - a 1988 update", Proceedings of. 15th Canadian Rock Mechanics Symposium, J.H. Curran (ed), Toronto: Civil 
Engineering Dept., University of Toronto. pp. 3138.

[6] Duncan, C. W. and Christopher W. M. (2004), Rock slope engineering: civil and mining, Institute of Mining and Metallurgy and E. Hoek and J. W. Bray, 4th Edition. Spon Press, New York. 456 pp.

[7] Hoek, E. and Bray, J. (1981) Rock Slope Engineering, Institute of Materials, Minerals and Mining, London, London, UK, 3rd Edition, pp. 1013-1035.

[8] Brown, A. (1982), "The influence and control of groundwater in large slopes", Stability in Surface Mining, C.O. Brawner (ed), New York: Society of Mining Engineers, AIME, pp. 19-41.

[9] Hoek, E. (2006), "Practical Rock Engineering", Unpublished Text Book, 2006 revised edition, 341pp.
[10] Griffiths, D. V. and Lane, P. A. (1999), "Slope stability analysis by finite elements", Geotechnique, Vol. 49, No. 3, pp. 387-403.

[11] Bukari, E. M. (2001), "Slope stability Analysis at Abosso Goldfields Limited", Unpublished BSC. Project Report, University of Mines and Technology pp. 3.

[12] Hudson, J. A. (1989), Rock Mechanics Principles in Engineering Practice, CIRIA/Butterworths, London, 72pp.

[13] Dadzie, E., Abdulai, M. and Baku, A. "Sustainability of Innovative Management Practices of Geotechnical Risk at Damang Pit Cutback (DPCB) - A Case Study at GoldFields Ghana, Damang Mine", Unpublished BSc Project Report, University Denison, Canada, 2006.

[14] Agyei, G., Osei, J.B. and Adoko, A.C. "Slope Stability Analysis of Nkran Pit at Asanko Gold Mine, Ghana", J. of Appl. Sci. and Environ. Management, 22 (10), 2018: 1647-1653. 